\title{
Voting Behavior in Parliamentary Elections in Slovakia
}

\author{
Miroslav Ř́dek ${ }^{1}$
}

\begin{abstract}
Department of Political Science at Alexander Dubcek University in Trencin prepared its own exit poll during election day on March 5, 2016. The survey asked seven questions that were aimed at determining the preferences of the respondents concerning not only the current but also past general elections. Interviewers surveyed the choice of political party or movement in parliamentary elections in 2016 as well as preferences in past elections. Followed by questions concerning motivation to vote - when did the respondents decide to go to vote and what or who inspired this decision. The survey also tried to found out how many preferential votes did the voters give to the candidates of political parties and movements. Final question asked about expectations for the future of individual respondents. This article is the information output of the survey. The interviewers were 124 university students and its return was 1,612 sheets. The aim of this paper is to communicate the findings of this unique survey, which is unprecedented in the Slovak political science.
\end{abstract}

KEY WORDS: election, political parties, voters, parliament, electoral behavior

\section{INTRODUCTION}

Voting behavior was one of the main focus points of research in social science for the greater part of the twentieth century. Historically it followed development of the competitive politics in liberal democracies. A newly found interest in forecasts of outcomes of elections, referendums and plebiscites motivated researchers to develop opinion polling methods in US and subsequently also in Western Europe. The popularization of research went hand in hand with the development of scientific discourse and growth of specialized literature. The relationship between developing theory and empirical experience is well described by Dušan Polonský in his work Úvod do sociologického výskumu: "Sociological research unavoidably stems from some theory and implicitly contains some theoretical generalizations. Therefore it can be qualified as: a) empirical or particular research and b) theoretical research. In empirical research the main goal is gaining knowledge based on direct study of social phenomenon, object of thing; on the other hand theoretical research is mostly concentrated on conclusion of theoretical generalizations with broader validity, especially theories, scientific hypotheses and so on, especially based on findings gained by

${ }^{1}$ PhDr. Miroslav Řádek, PhD. Alexander Dubček University in Trenčín, Department of Political Science, 91150 Trenčín, Slovak Republic, e-mail: miroslav.radek@tnuni.sk 
concrete (empirical) researches, conducted perhaps on the ground of other scientific disciplines" (Polonský, 2000, p. 9). Cited relationship is a part of heuristic - generally a praxis of discovering methods to solve problems.

Practical and theoretical development of sociology has gradually brought several methods of public opinion research. Research of social reality and its correlations is conducted in several ways today. There are numerous different kinds of sociological research. "It is possible to divide sociological researches as a whole according to these substantial signs: according to the nature of the researched phenomena, according to the scientific goals of the research, or according to the intensity of the research of the social phenomena, according to degree of complexity of research realization, according to time dimension of the research" (Polonský, 2000, p. 23). According to these criteria we can theoretically distinguish several types of research: basic, applied, complex, partial, replicated, single-time and longitudinal.

A few private agencies are currently involved in conducting sporadic practical research of electoral support of political parties and movements and selected individual politicians. The Public is informed of the measured levels of support through media, which are also often ordering the research form the agencies. The Slovak parliamentary elections of 2016 were conducted according to new legislative rules concerning opinion polls, which prohibited their publication in 2 week period before the election.

In Table 1 we can see what was the electoral support for political parties right before the general election according to opinion polls of relevant agencies.

Based on development of poll results for political parties since the summer of 2015 it was possible to notice trends for voter support for individual political subjects. According to those it was apparent that Smer-SD, Siet', SNS, Most-Híd and $\mathrm{KDH}$ were going to be the parliamentary parties after the election. Parties OL'aNO (with members of NOVA movement on their candidate list) and SaS were not sure to get to the parliament according to the data in Table 1. SaS had support of around $5 \%$ of voters. OLaNO movement experienced a decline form $7 \%$ to $5 \%$ in the final months prior to the election. Finally it was the political scandal concerning allegation of Igor Matovic the leader of the movement of tax evasion by the chairman of Smer-SD, that helped the voting support of OLaNO to rebound. As for $\mathrm{KDH}$, which had a continuous parliamentary presence since 1990, opinion polls showed gradual decline of its voter support as well.

Concerning opinion polls we need to add that pre-election support for political parties is affected by numerous variables of psychological nature and that uncertainty about electoral results is heightened by the amount of time before the elections. Researchers suggest that the decision-making moment of voters to vote for specific party is moving ever closer to the elections itself. This is one of the reasons why using different type of research - called exit poll - can 
get us more information concerning voting behavior. With this kind of poll the pollsters are questioning the respondents in the moment when they are leaving the voting booth. Its main advantage is that respondents are giving relatively most truthful information compared to other types of polls. Voters have fresh memories not only of the party they voted for but also of particular candidates and their number as well as other details of their decision-making.

Table 1: Final polls for political parties before the election

\begin{tabular}{|l|c|c|c|c|c|}
\hline & Ako & Focus & Median & MVK & Polis \\
\hline Smer-SD & $35 \%$ & $34,60 \%$ & $36 \%$ & $34,50 \%$ & $38,40 \%$ \\
\hline Siet' & $8,10 \%$ & $14,00 \%$ & $8,10 \%$ & $14,70 \%$ & $10,40 \%$ \\
\hline SNS & $9,40 \%$ & $8,70 \%$ & $10,70 \%$ & $10,10 \%$ & $9,10 \%$ \\
\hline Most-Híd & $6,90 \%$ & $8,20 \%$ & $9,90 \%$ & $6,50 \%$ & $9,20 \%$ \\
\hline KDH & $6,30 \%$ & $7,00 \%$ & $6 \%$ & $8,60 \%$ & $6,60 \%$ \\
\hline OL'aNO-NOVA & $6,90 \%$ & $6,10 \%$ & $8,60 \%$ & $5 \%$ & $6,80 \%$ \\
\hline SaS & $6,70 \%$ & $5,50 \%$ & $6,30 \%$ & $3,40 \%$ & $5,20 \%$ \\
\hline Sme rodina & $5,10 \%$ & $4,20 \%$ & $4 \%$ & $2,7 \%$ & $3,60 \%$ \\
\hline SMK & $3 \%$ & $3,50 \%$ & $2,40 \%$ & $5,10 \%$ & $4 \%$ \\
\hline L'S-NS & $4,20 \%$ & $2,10 \%$ & $1,80 \%$ & & $2,50 \%$ \\
\hline Šanca & $0,40 \%$ & $1,60 \%$ & $0,50 \%$ & & \\
\hline SDKÚ-DS & $0,70 \%$ & $1 \%$ & $0,90 \%$ & & $1,30 \%$ \\
\hline SKOK & $2,30 \%$ & $1 \%$ & $0,70 \%$ & & \\
\hline
\end{tabular}

Note: data was summarized according to information published in articles of SME and Pravda newspapers

We decided to conduct a research of voting behavior during general election of 2016. The research was based on an exit poll with seven questions concerning: timing of decision to participate on election, identification of intermediate variable, participation on previous elections, assigning of preferential votes and expectations for the future. Based on these questions we aimed to find out: when and why did the voters decide to vote for particular party, electoral volatility, assigning of preferential votes to candidates and emotional scale of voters. The poll was conducted on March 5, 2016 by 124 students in the role of pollsters with 1612 recovered questionnaires. The respondents came from all Slovak regions and structure of age, sex and education was representative of general voting population. 
The poll hinted at strong decline of support (down to 24\%) for ruling party SmerSD. It also confirmed chances of SNS to get back to parliament with support higher than $10 \%$. Also higher than $10 \%$ was support for SaS. OLaNO-NOVA movement gained support of over $8 \%$. The poll confirmed that parties Kotleba L'S-NS and Sme rodina would get to parliament as well, while it shown that Siet' party failed to fulfill its hopes to become the strongest centre-right party. The poll suggested that KDH movement would get to parliament, which did not happened by a small margin and this outcome was still within the margin of error of the poll.

Graph 1: Estimated gains (\%) of political parties and movements in the 2016 parliamentary elections.

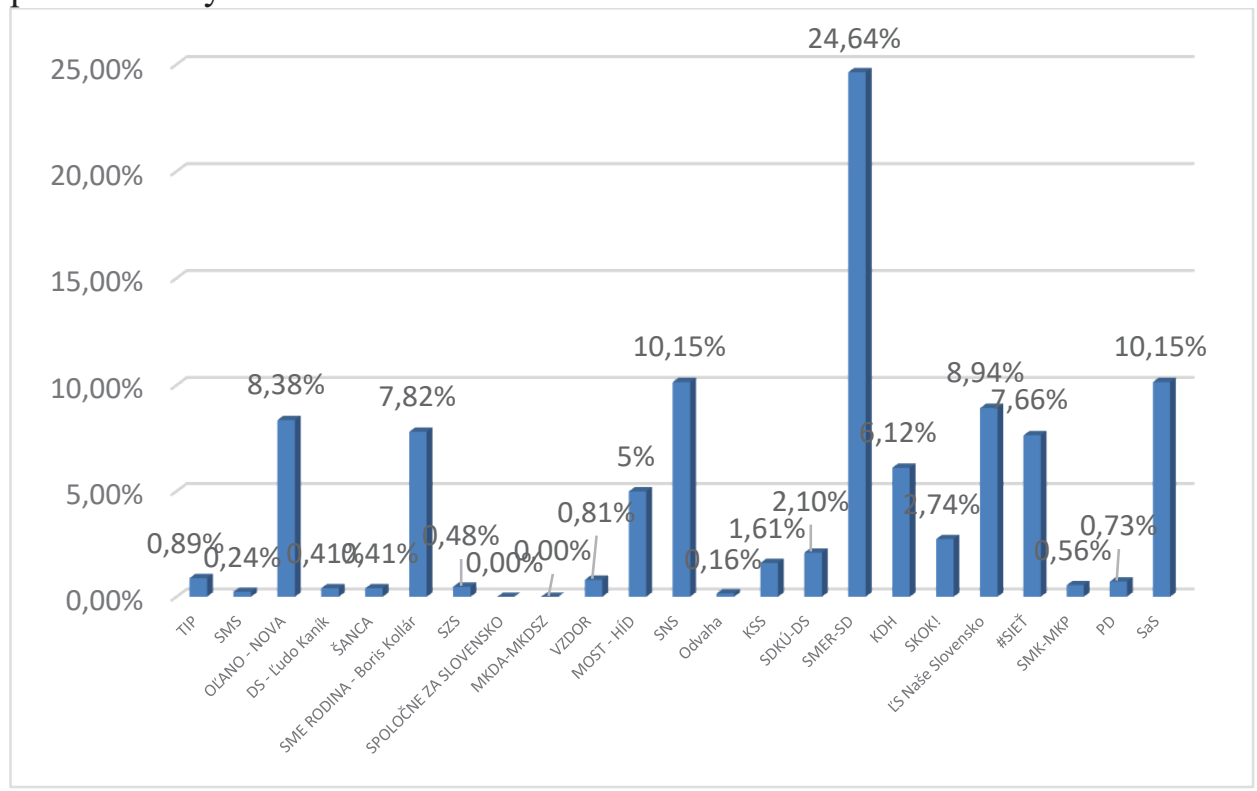

\section{WHEN AND WHY DID VOTERS DECIDED TO ATTEND THE ELECTIONS}

Question no. 1 is asking "approximately when did you decide to attend the elections?". To determine the time of decision-making, there was a scale with six categories: at least 6 months ago, at least 3 months ago, at least a month ago, at least 2 weeks ago, about a week ago and today. The results shown that slightly more than half of respondents decided to vote at least 6 months ago. Relatively smaller part made the decision about 3 months ago (11\%). Some $38 \%$ made the decision in the time period of around a month before the elections or shorter. 
About $11 \%$ of respondents made their decision on the election day. Some $12 \%$ of voters decided a month before elections.

Graph 2: Time factor of decision-making about electoral participation

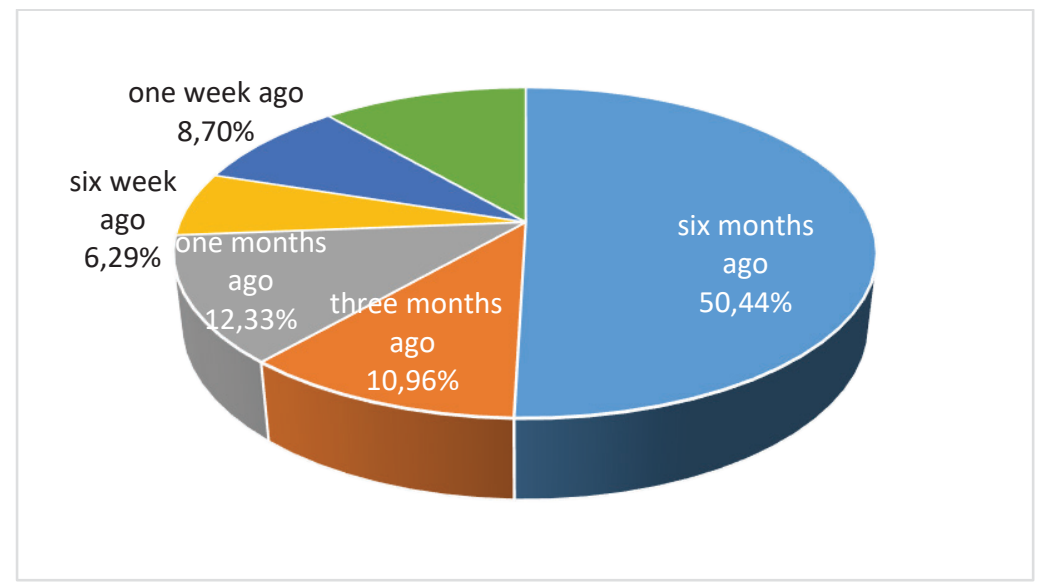

The second question, which concerned the motives of electoral participation, also offered six possible ways to answer. Respondents were choosing between: family, friends, working environment, media, state of society, or other motives. Almost a half of respondents said that state of society was their main motivation for attending the election. The second most common answer was family influence (16\%). Surprising was the outcome for media (9\%) and working environment (2\%). These findings support interpretation of Oskar Krejčí about agents of political socialization. "It is remarkable how weak effect was expected of the mass media by the authors of the graph (Estimated influence of factors during socialization). However even in this form is the graph very informative. Perhaps the most remarkable is the changing role of generational layer in political socialization during adolescence and after it, which has been proven by many researches. Every discussion about this graph must take into consideration noted fact, that majority of the researches took place in United States. The scheme of political socialisation would look different in traditional societies, where the influence of family is stronger" (Krejčí, 2004, p. 118). 
Graph 3: Factors of electoral participation

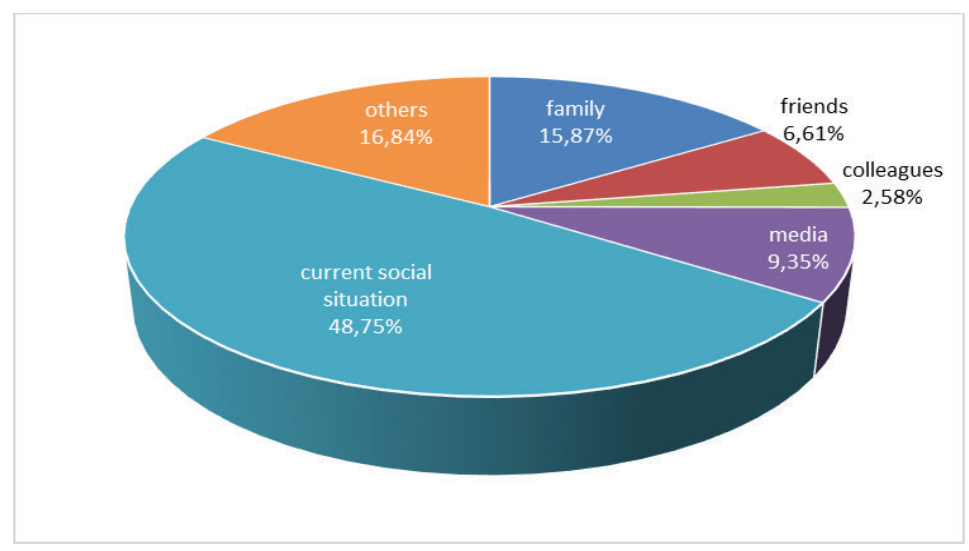

With the first two questions we were interested about match or difference of factors of electoral participation form respondents who decided at least three months before elections compared to respondents who decided closer than three months before the elections. We can see the outcomes in Table 2 below:

Table 2: Factors of participation related to time of decision-making

\begin{tabular}{|l|c|c|}
\hline & 3 and more months & 3 months - election day \\
\hline family & $11,48 \%$ & $22,92 \%$ \\
\hline friends & $3,69 \%$ & $11,25 \%$ \\
\hline working environment & $1,45 \%$ & $4,38 \%$ \\
\hline media & $8,18 \%$ & $11,25 \%$ \\
\hline state of society & $57,39 \%$ & $35,21 \%$ \\
\hline other & $17,81 \%$ & $14,99 \%$ \\
\hline
\end{tabular}

According to our findings the motivations of voters decided earlier (3 months and more) and of voters decided later (less than 3 moths before elections) were somewhat different. Factors of family, state of society and others were present in both studied categories, while in category of voters decided earlier there was relatively stronger presence of state of society $(57,39 \%)$, which voters decided later stated only in about $35 \%$ of cases. Besides that the category of voters decided later was influenced more strongly by friends and media (both in 11,25\% of cases). We can note that in the design of the questionnaire was the answer category other added as complementary possibility. Since it ended up being the 
second most common answer, it would be useful to break it down into new categories in future researches.

\section{ELECTORAL VOLATILITY}

During a quarter of century of existence the competitive party system has shown its instability. The research has captured its transformations from extreme multipartism (1998 - 2002) towards moderate multipartism (2002-2010) towards dominant party tendencies $(2012$ - 2016) and now back towards extreme multipartism (since 2016). Research of electoral volatility has to be a part of searching for causes of these changes. Voter turnout in parliamentary elections of 2016 was the same as in parliamentary elections of $2012-59 \%$. However, according to our poll some $9 \%$ of voters had changed between the two elections. $78.97 \%$ of voters in the 2016 elections were also attending the elections of 2012. We are going to try to find out how did the voters change their party preferences between the two elections and who did the non-voters of 2012 and the first-time voters voted for in 2016 elections.

\section{1 Composition of Smer-SD voters}

Political party Smer-SD had among its voters in 2016 comparatively highest percentage of voters who already participated on elections of 2012 (91,36\%). $84,8 \%$ of people voting for Smer-SD in 2016 also voted for this party in 2012 elections. Only 8,64\% of Smer-SD voters in 2016 were non-voters in previous elections and former voters of other parties were of very little significance here (former voters of both KDH and OLaNO now formed 1,64\% of Smer-SD voters respectively).

Table 3: Voting of present day Smer-SD voters in 2012

\begin{tabular}{|l|c|}
\hline political party & percentage share \\
\hline Krest'anskodemokratické hnutie & $1,64 \%$ \\
\hline Strana demokratickej l'avice & $0,33 \%$ \\
\hline Slovenská národná strana & $0,98 \%$ \\
\hline Obyčajní l'udia a nezávislé osobnosti & $1,64 \%$ \\
\hline Sloboda a Solidarita & $0,98 \%$ \\
\hline Smer - sociálna demokracia & $84,8 \%$ \\
\hline Komunistická strana Slovenska & $0,33 \%$ \\
\hline Strana rómskej unie na Slovensku & $0,33 \%$ \\
\hline 99\% - občiansky hlas & $0,33 \%$ \\
\hline non-voters in the 2012 parliamentary elections & $8,64 \%$ \\
\hline
\end{tabular}




\section{2 Composition of SaS voters}

$\mathrm{SaS}$ voters in 2016 have much more colorful composition than Smer-SD voters as far as their voting preferences in 2012 elections are concerned. Slightly less than half of liberal voters in 2016 elections voted for SaS also in 2012 elections. Others used to be Smer-SD voters (9,52\%), OLaNO voters (7,14\%) and SDKÚDS voters $(3,97 \%)$. The rest of he parties represented less than $3 \%$. Nearly one fifth of $2016 \mathrm{SaS}$ voters did not participate on 2012 elections. Voting preferences of $2016 \mathrm{SaS}$ voters in 2012 elections are shown in the Table 4 below.

Table 4: Voting of present day SaS voters in 2012

\begin{tabular}{|l|c|}
\hline political party & percentage share \\
\hline Zelení & $2,38 \%$ \\
\hline Krest'anskodemokratické hnutie & $2,38 \%$ \\
\hline Obyčajní l'udia a nezáviské osobnosti & $7,14 \%$ \\
\hline Sloboda a Solidarita & $46,83 \%$ \\
\hline Strana zelených & $0,79 \%$ \\
\hline L’udová strana Naše Slovensko & $0,79 \%$ \\
\hline Smer - sociálna demokracia & $9,52 \%$ \\
\hline Zmena zdola, Demokratická únia Slovenska & $0,79 \%$ \\
\hline Národ a spravodlivost' & $0,79 \%$ \\
\hline Most-Híd & $0,79 \%$ \\
\hline 99\% - občiansky hlas & $0,79 \%$ \\
\hline L'udová strana - Hnutie za demokratické Slovensko & $0,79 \%$ \\
\hline Obyčajní l'udia & $2,38 \%$ \\
\hline SDKÚ-DS & $3,97 \%$ \\
\hline non-voters in the 2012 parliamentary elections & $19,87 \%$ \\
\hline
\end{tabular}

\section{3 Composition of OLaNO-NOVA voters}

"Electoral history" of OLaNO-NOVA voters was even more fragmented. Just (!) one quarter of their voters already voted for this movement led by Igor Matovic in the 2012 elections. Second largest group of their 2016 voters voted for $\mathrm{SaS}$ in 2012. Third most populous was the group of former KDH voters $(11,54 \%)$. And every tenth voter used to be a Smer-SD voter four years ago. 4,81\% of 2016 voters for the OLaNO-NOVA movement were voting SDKÚ-DS in 2016. Every fifth OLaNO-NOVA voter in the 2016 elections was a non-voter four years ago. 
Table 5: Voting of present day OL'aNO-NOVA voters in 2012

\begin{tabular}{|l|c|}
\hline political party & percentage share \\
\hline Krest'anskodemokratické hnutie & $11,54 \%$ \\
\hline Obyčajní l'udia a nezávislé osobnosti & $25,96 \%$ \\
\hline Sloboda a Solidarita & $18,27 \%$ \\
\hline Smer - sociálna demokracia & $8,65 \%$ \\
\hline Most-Híd & $3,85 \%$ \\
\hline Obyčajní l'udia & $5,77 \%$ \\
\hline SDKÚ-DS & $4,81 \%$ \\
\hline Strana Slobodné Slovo - Nory Mojsejovej & $0,96 \%$ \\
\hline non-voters in the 2012 parliamentary elections & $19,23 \%$ \\
\hline
\end{tabular}

\section{4 Composition of SNS voters}

SNS party was left just outside of the gates of parliament in the 2012 elections. During the 2012-2014 period it went through replacement of leadership, which was communicated in long marketing campaign lasting up until the 2016 elections. Therefore it is interesting to find out how did the new political identity translate into a change of composition of SNS voters in the 2016 elections. Exit poll discovered that one third of SNS voters in 2016 also voted for the party in 2012. Another third of voters were former Smer-SD voters from 2012. More than $5 \%$ of SNS voters in 2016 voted for conservative KDH in 2016. There was minimal presence of former voters for any other parties. More than $22 \%$ of SNS voters were non-voters four years ago.

Table 6: Voting of present day SNS voters in 2012

\begin{tabular}{|l|c|}
\hline political party & percentage share \\
\hline Krest'anskodemokratické hnutie & $5,56 \%$ \\
\hline Slovenská národná strana & $30,95 \%$ \\
\hline Obyčajní l'udia a nezávislé osobnosti & $0,79 \%$ \\
\hline Sloboda a Solidarita & $0,79 \%$ \\
\hline Strana zelených & $0,79 \%$ \\
\hline L’udová strana Naše Slovensko & $0,79 \%$ \\
\hline Smer - sociálna demokracia & $31,75 \%$ \\
\hline Komunistická strana Slovenska & $0,79 \%$ \\
\hline L'udová strana - Hnutie za demokratické Slovensko & $1,59 \%$ \\
\hline Obyčajní l'udia & $1,59 \%$ \\
\hline SDKÚ-DS & $2,38 \%$ \\
\hline non-voters in the 2012 parliamentary elections & $22,23 \%$ \\
\hline
\end{tabular}




\section{5 Composition of Kotleba LS-NS voters}

One of the perceived surprises of the 2016 elections was that L'S-NS party passed the parliamentary threshold. The party changed its name shortly before the elections by adding the name of its leader in front of its name. It was a practical step already tried out by other parties in the past and aimed to make the party more recognizable. In case of Kotleba L'S-NS it served the purpose of gaining support using party leader and make it easier to recognize among competition.

Leader of Kotleba L'S-NS party is known for his support of authoritarian, antisemitic and chauvinist ideas. Success of the L'S-NS was not entirely without warning. A week before the elections there were some observations, which were summed up by Martin Hanus (2016) in his article in Postoj newspaper: "The well informed behind the curtain sources have been talking for the past few days of opinion polls ordered by political parties (the results of which can not be published because of two weeks long moratorium) and showing the rise of support for LS-NS. The rise of support is so significant that it gives the party a chance to get into parliament. Also there has been a rise of Facebook activity among supporters of Kotleba in the past few weeks. Kotleba has some 55 thousand followers on Facebook (Radoslav Procházka only has 30 thousand) and they are very active. When the overloaded regional chairman recently complained about regional MPs trying to curb his powers again, he received almost 2000 likes and 900 shared it on their page. Similarly devoted fans could probably only be found on the Slovak Internet among sympathizers of Sme rodina or SaS."

What kind of voters supported the neo-nazi party on Marian Kotleba? The exit poll discovered that the largest group among LS-NS voters in 2016 were the non-voters in 2012 (almost 42\%). The second largest group were the former voters of Smer-SD, which now represented $18 \%$ of LS-NS voters. The original LS-NS voters from elections of 2012 were only the third largest group of voters this year. The fourth largest group were the former voters of SDL $(6,31 \%)$.

Table 7: Voting of present day Kotleba LS-NS voters in 2012

\begin{tabular}{|l|c|}
\hline political party & percentage share \\
\hline Krest'anskodemokratické hnutie & $3,6 \%$ \\
\hline Strana demokratickej l'avice & $6,31 \%$ \\
\hline Obyčajní l'udia a nezávislé osobnosti & $2,7 \%$ \\
\hline Sloboda a Solidarita & $2,7 \%$ \\
\hline Strana zelenych & $0,9 \%$ \\
\hline L’udová strana Naše Slovensko & $14,41 \%$ \\
\hline Smer - sociálna demokracia & $18,02 \%$ \\
\hline
\end{tabular}




\begin{tabular}{|l|c|}
\hline Komunisticka strana Slovenska & $0,9 \%$ \\
\hline Most-Híd & $1,8 \%$ \\
\hline 99\% - občiansky hlas & $0,9 \%$ \\
\hline L'udová strana - Hnutie za demokratické Slovensko & $0,9 \%$ \\
\hline STRANA +1 HLAS & $0,9 \%$ \\
\hline SDKÚ-DS & $1,8 \%$ \\
\hline Strana občanov Slovenska & $0,9 \%$ \\
\hline Strana Slobodné Slovo - Nory Mojsejovej & $0,9 \%$ \\
\hline Strana živnostníkov Slovenska & $0,9 \%$ \\
\hline non-voters in the 2012 parliamentary elections & $41,46 \%$ \\
\hline
\end{tabular}

\section{6 Composition of Sme rodina voters}

Another political party that surprised by passing the threshold to parliament was Sme rodina party led by well known businessman Boris Kollar. The success of this loud entrepreneur was all the greater because he only started his political project four months before the elections. The organization of the movement was in the hands of former KDH members and later also NOVA members grouped around Milan Krajniak. Therefore its ideological profile is close to protest and conservatism and we can expect it to remain stable.

Similarly to the L'S-NS party, also the voters of Sme rodina movement in 2016 elections consisted mostly of former non-voters in the 2012 elections (almost 50\%). The next largest groups were the relatively conservative voters, who voted for OLaNO $(11,34 \%)$ and $\mathrm{KDH}(7,22 \%)$ in the 2012 elections. But there were also more liberal former SaS voters $(8,25 \%)$. The movement attracted few former Smer-SD voters $(4,12 \%)$, however it did well among former voters of alternative parties - LS-NS, 99\% - občiansky hlas and Strana Slobodne Slovo - Nory Mojsejovej (together they represented almost 10 of voters for the movement).

Table 8: Voting of present day Sme rodina voters in 2012

\begin{tabular}{|l|c|}
\hline political party & percentage share \\
\hline Zelení & $1,03 \%$ \\
\hline Krest'anskodemokratické hnutie & $7,22 \%$ \\
\hline Slovenská národná strana & $5,15 \%$ \\
\hline Obyčajní l'udia a nezáviské osobnosti & $11,34 \%$ \\
\hline Sloboda a Solidarita & $8,25 \%$ \\
\hline Ludová strana Naše Slovensko & $3,09 \%$ \\
\hline Smer - sociálna demokracia & $4,12 \%$ \\
\hline Most-Híd & $1,03 \%$ \\
\hline $99 \%$ - občiansky hlas & $3,09 \%$ \\
\hline
\end{tabular}




\begin{tabular}{|l|c|}
\hline Obyčajní l'udia & $2,06 \%$ \\
\hline SDKÚU-DS & $1,03 \%$ \\
\hline Strana Slobodné Slovo - Nory Mojsejovej & $3,09 \%$ \\
\hline non-voters in the 2012 parliamentary elections & $49,5 \%$ \\
\hline
\end{tabular}

\section{7 Composition of Most-Híd voters}

Since its founding in 2009 the Most-Híd party kept an image of civic party that tried to connect voters with different nationality as well as liberal and conservative voters. Therefore there is no surprise that half of its voters in 2016 elections were its voters already in 2012 and the other groups of its voters this year were former voters of SDKÚ-DS $(8,06 \%), \mathrm{KDH}$ and $\mathrm{SaS}(3,23 \%$ each). Interesting thing is that it also gained significant support from former Smer-SD voters $(17 \%)$ and even from former SNS voters $(3,23 \%)$. On the other hand only small part of their voters in 2016 were former SMK voters (4\%) which is their main competition.

Table 9: Voting of present day Most-Híd voters in 2012

\begin{tabular}{|l|c|}
\hline political party & $\begin{array}{c}\text { percentage } \\
\text { share }\end{array}$ \\
\hline Krest'anskodemokratické hnutie & $3,23 \%$ \\
\hline Slovenská národná strana & $3,23 \%$ \\
\hline Sloboda a Solidarita & $3,23 \%$ \\
\hline Smer - sociálna demokracia & $17,74 \%$ \\
\hline Most-Híd & $50 \%$ \\
\hline SDKÚ-DS & $8,06 \%$ \\
\hline Strana mad'arskej koalície - Magyar Koalíció Pártja & $4,84 \%$ \\
\hline non-voters in the 2012 parliamentary elections & $9,67 \%$ \\
\hline
\end{tabular}

\section{8 Composition of Siet' voters}

The final surprise was the outcome for Siet' party, which was led by Radoslav Procházka - former KDH member and MP. He founded the new centre right party in 2014 after failing to become the president. The actual political strategy of Siet' however targeted also the Smer-SD sympathizers. This was apparent when Siet' was not among the toughest criticizers of the social democrats and Radoslav Procházka refused to rule out Smer-SD as a potential partner. This strategy turned out to be harmful towards the end of campaign. SaS and OLaNO both took tough stances against Robert Fico and his party and it was this appeal that helped them mobilize the undecided center right voters. The result was weak support for Siet. One fifth of its voters in 2016 elections were former Smer-SD 
voters from 2012 elections. But Siet' had much weaker support among former SDKÚ-DS voters $(11,59 \%$ of Siet' voters in 2016), former KDH and OLaNO voters $(8,42 \%$ each) and former $\mathrm{SaS}$ voters $(7,73 \%)$.

Table 10: Voting of present day Siet' voters in 2012

\begin{tabular}{|l|c|}
\hline political party & percentage share \\
\hline Krest'anskodemokratické hnutie & $8,42 \%$ \\
\hline Slovenská národná strana & $7,37 \%$ \\
\hline Obyčajní l'udia a nezávislé osobnosti & $8,42 \%$ \\
\hline Sloboda a Solidarita & $7,37 \%$ \\
\hline Smer - sociálna demokracia & $21,05 \%$ \\
\hline Most-Híd & $2,11 \%$ \\
\hline 99\% - občiansky hlas & $1,05 \%$ \\
\hline SDKÚ-DS & $11,59 \%$ \\
\hline Strana živnostníkov & $1,05 \%$ \\
\hline non-voters in the 2012 parliamentary elections & $31,57 \%$ \\
\hline
\end{tabular}

\section{PREFERENTIAL VOTES AND EXPECTATIONS OF VOTERS}

The Voters were using preferential voting over the past decade increasingly often as a tool to express their opinions. The Statistical Office of the Slovak Republic keeps an evidence of preferential votes for individual candidates of political parties and movements, however these statistics can not tell us how many preferential votes do individual voters use. For that reason we added a question whether and how many preferential votes did respondents award to the candidates. Results shown that only $21 \%$ of voters did not support any of the candidates with preferential votes. Which means that four out of five voters used them. The largest group (35\%) of voters used all four preferential votes, followed by $17 \%$ of voters who used only one preferential vote. There was $27 \%$ of voters that used either two or three preferential votes. 
Graph 4: Preferential voting in parliamentary elections of 2016

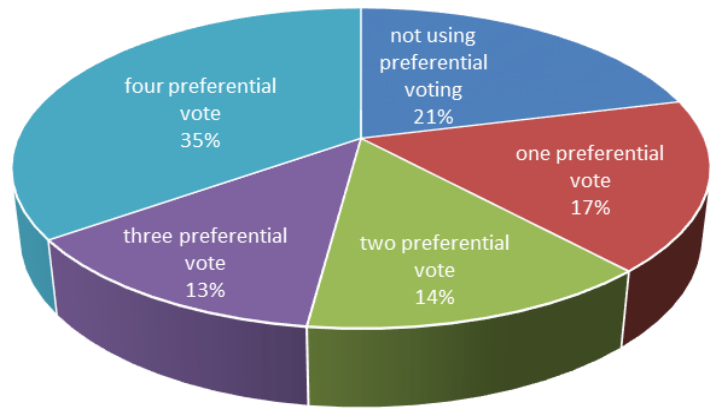

We also wanted to find out if there was a difference between the voters of relevant political parties in respect to using preferential votes. Respondents not using preferential voting at all were especially among the voters of Siet, SNS and Smer-SD. Only one preferential vote was used more frequently among the voters of Kotleba L'S-NS. Two preferential votes were used more often by the voters of Sme rodina and three votes were used more frequently by the voters of MostHíd. Voters of SNS used all four preferential votes more often than voters of other parties.

Table 11: Preferential voting among voters of relevant political parties

\begin{tabular}{|c|c|c|c|c|c|}
\hline & no vote & 1 vote & 2 votes & 3 votes & 4 votes \\
\hline Smer-SD & $23,28 \%$ & $12,79 \%$ & $9,51 \%$ & $14,4 \%$ & $40,32 \%$ \\
\hline SaS & $16,6 \%$ & $15,87 \%$ & $15,87 \%$ & $13,49 \%$ & $38,17 \%$ \\
\hline OLaNO & $9,62 \%$ & $22,12 \%$ & $15,38 \%$ & $10,58 \%$ & $42,3 \%$ \\
\hline SNS & $24,60 \%$ & $14,29 \%$ & $15,87 \%$ & $13,49 \%$ & $68,25 \%$ \\
\hline LS-NS & $15,32 \%$ & $29,73 \%$ & $10,81 \%$ & $14,41 \%$ & $29,73 \%$ \\
\hline $\begin{array}{c}\text { Sme } \\
\text { rodina }\end{array}$ & $20,62 \%$ & $22,68 \%$ & $22,68 \%$ & $3,09 \%$ & $30,93 \%$ \\
\hline Most-Híd & $14,52 \%$ & $17,74 \%$ & $16,13 \%$ & $17,74 \%$ & $33,87 \%$ \\
\hline Siet' & $27,39 \%$ & $12,63 \%$ & $13,68 \%$ & $13,68 \%$ & $32,62 \%$ \\
\hline
\end{tabular}

Expectations of voters during the 2016 parliamentary elections could be summed up as guarded optimism. Majority of voters when asked "What is the situation in Slovakia going to be like after the 2016 parliamentary elections?" replied "I do not know" or "about the same", which represents about three fifths of all 
respondents. One third expected "somewhat better" or "definitely better" situation. Only $9 \%$ expressed opposite expectations.

Graph 5: Expectations of voters after parliamentary elections of 2016

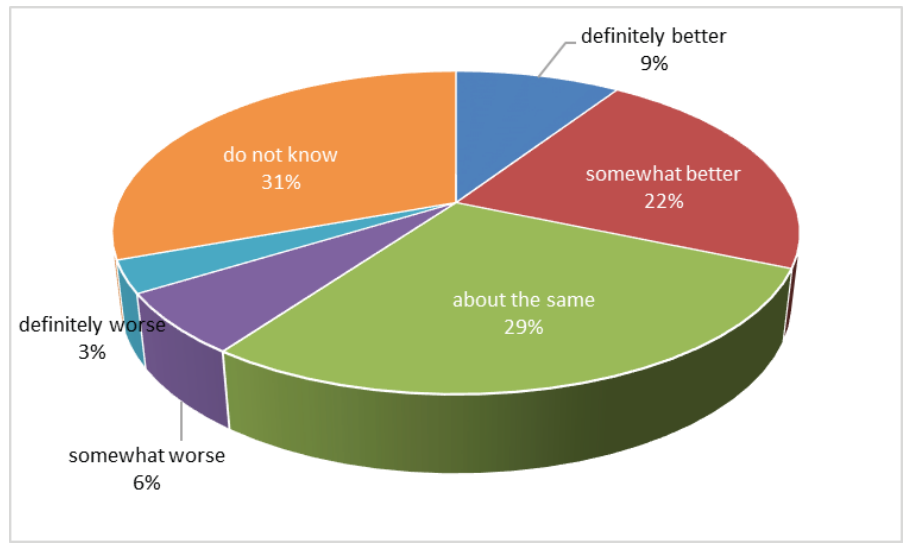

The sentiment of voters of relevant political parties is captured in greater detail in Table 12. The largest share of respondents unable to express their expectations was among the voters of SaS and OLaNO-NOVA (more than 40\%) and among the voters of Siet' (more than 30\%). The largest share of respondents expecting no change for better or worse was among the voters of Smer-SD and SNS. To smaller extent it is also truth about the voters of Sme rodina, Most-Híd and Siet'. Slightly optimstic were voters of Most-Híd, Kotleba LS-NS and OLaNO. On the other hand slightly pessimistic were the voters of Sme rodina party. The biggest share of clear optimists was among the voters of Most-Híd and Kotleba LS-NS. That was paradoxically also the party with the largest share of clear pessimists (9\%) with Most-Híd being second (4,84\%).

Table 12: Expectations of voters of relevant political parties

\begin{tabular}{|c|c|c|c|c|c|c|}
\hline & $\begin{array}{c}\text { Do not } \\
\text { know }\end{array}$ & $\begin{array}{c}\text { definitely } \\
\text { better }\end{array}$ & $\begin{array}{c}\text { somewhat } \\
\text { better }\end{array}$ & $\begin{array}{c}\text { about the } \\
\text { same }\end{array}$ & $\begin{array}{c}\text { somewhat } \\
\text { worse }\end{array}$ & $\begin{array}{c}\text { definitely } \\
\text { worse }\end{array}$ \\
\hline Smer-SD & $21,31 \%$ & $14,44 \%$ & $21,31 \%$ & $37,38 \%$ & $4,59 \%$ & $0,98 \%$ \\
\hline SaS & $40,47 \%$ & $2,38 \%$ & $25,4 \%$ & $23,81 \%$ & $3,97 \%$ & $3,97 \%$ \\
\hline OLaNO & $40,38 \%$ & $7,69 \%$ & $22,12 \%$ & $19,23 \%$ & $6,73 \%$ & $3,85 \%$ \\
\hline SNS & $27,78 \%$ & $9,52 \%$ & $21,43 \%$ & $31,75 \%$ & $8,73 \%$ & $0,79 \%$ \\
\hline L'S-NS & $28,83 \%$ & $15,32 \%$ & $24,32 \%$ & $18,92 \%$ & $3,6 \%$ & $9,01 \%$ \\
\hline Sme rodina & $11,33 \%$ & $7,22 \%$ & $20,62 \%$ & $30,93 \%$ & $20,62 \%$ & $2,06 \%$ \\
\hline Most-Híd & $4,23 \%$ & $31,25 \%$ & $27,42 \%$ & $30,65 \%$ & $1,61 \%$ & $4,84 \%$ \\
\hline Siet' & $32,63 \%$ & $8,42 \%$ & $21,05 \%$ & $30,53 \%$ & $5,26 \%$ & $2,11 \%$ \\
\hline
\end{tabular}




\section{CONCLUSION}

Results of research of the Department of Political Science at Alexander Dubček University in Trenčín "Exitpoll NR SR 2016" include not only the usual estimate of the election outcomes but also valuable findings concerning voting behavior. Estimate of election outcomes differed form the actual outcomes only in the case of Smer-SD party. It estimated the electoral support of other political parties within the limits of standard statistical error.

The research discovered that half of the voters were decided to participate in the elections at least 6 moths before it took place. Every tenth voter decided to participate about 3 months before the elections and $36 \%$ of voters decided during the last month before the election.

The main motivation to attend the elections was clearly the state of society, which can be understood as expression of dissatisfaction. Surprisingly the second most common motivation was category "other" which shows that possible answers offered to the respondents were not sufficient and the questionnaire might need reformulation in the future. On the third place - hinting at out traditionalism - respondents placed family influence, which was roughly as strong as influence of media and friends together. Influence of working environment was very weak.

Among other significant findings of exit poll there are notable shifts of support for political parties between parliamentary elections of 2012 and 2016. The poll found relative consistence of Smer-SD voters which is unique among Slovak political parties. Other parliamentary parties witnessed significant volatility when they managed to gain former voters of other political parties or former non-voters. In case of parties Kotleba L'S-NS and Sme rodina these shifting voters represented majority of their electorate. We can also state that current coalition partners of Smer-SD were able to take significant part of its former voters in the 2016 elections.

The poll clearly confirmed interest of voters in using preferential votes. $80 \%$ of voters used it to support their candidates. It was typical for voters to use either all four $(35 \%)$ or just one $(17 \%)$ preferential vote. One third of voters gave their candidates either two or three preferential votes.

The last question in the poll was trying to identify expectations of voters for the next electoral term which we characterised as guarded optimism. We divided voters according to their sentiment into four basic groups - the largest group was insecure voters, second largest the people expecting stagnation, then the optimists (31\%) and finally pessimists representing less than $10 \%$ of respondents. 


\section{REFERENCES}

Hanus, M., 2016. Konzervatívny denník Postoj: Prízrak hnedého župana. [online]

February 29, 2016. Available at: https://www.postoj.sk/11321/prizrak-hnedeho-zupana [Accessed April 14, 2016].

Krejčí, O., 2004. Politická psychologie. Praha: Ekopress.

Polonský, D., 2000. Úvod do sociologického výskumu. Topol'čany: Primaprint. 